\title{
ASSESSMENT OF LV AND RV SYSTOLIC FUNCTIONS IN PATIENTS WITH CONNECTIVE TISSUE DISEASES BY 2D SPECKLE TRACKING ECHOCARDIOGRAPHY
}

\author{
By
Abdulrahman Ali Hussaini, Kamal Ahmed Merghany, Abd El-Hamid Ismail Abd El-Hamid and Mohamed Magdy Ghit \\ Department of Cardiology, Faculty of Medicine (Boys-Cairo), Al-Azhar University, \\ Department of Rheumatology and Rehabilitation
}

Corresponding author: Abdulrahman Ali Hussaini, Mobile: 01026234833

E-mail: 3bdulra7manz@gmail.com

\begin{abstract}
Background: Risk of development of cardiovascular disease (CVD), especially coronary artery disease (CAD) is increased in patients with connective tissue diseases (CTD). Data from previous studies showed double fold elevation in the risk of development of heart failure (HF) in CTD patients.

Objective: To assess left ventricular (LV) and right ventricular (RV) systolic functions in patients with CTD by $2 \mathrm{D}$ speckle tracking Echocardiography (STE).

Patients and Methods: This was a case-control study conducted on 120 subjects (100 connective tissue disease cases and 20 healthy controls) to assess LV systolic function and RV systolic function in connective tissue disease patients by $2 \mathrm{D}$ speckle tracking Echocardiography. Patients were classified according to presence of connective tissue diseases into 2 independent groups: Group A: connective tissue diseases patients (100 patients), and Group B: (20 healthy controls). All patients were recruited from the outpatient clinic in Al-Hussen University Hospital between September 2020 and April 2021.

Results: As regard Echocardiographic LV parameters of the studied groups, we found that there were significant differences between the groups regarding global longitudinal strain (GLS). (More negative GLS in CTDs patients) and mitral annular plane systolic excursion (MAPSE) $(\mathrm{P}<0.001)$. RV Echocardiography shows a significant difference between the groups regarding right ventricular end diastolic dimension (RVEDD), right ventricular end systolic dimension (RVESD), GLS (more negative GLS in CTDs patients) and tricusped annular plane systolic excursion (TAPSE) $(\mathrm{P}<0.001)$. There was a positive correlation between RV-GLS with TAPSE, while there was a negative correlation between RV-GLS with RVEDD and RVESD.

Conclusion: The GLS parameters in 2D speckle tracking echocardiography were a noninvasive costeffective tool with a desirable diagnostic value in patients with CTD. GLS impairment was common in 2D speckle tracking echocardiography findings in our patients with CTD and this was statistically significant, denoting early systolic function. Longer durations and high disease activity index significantly effect of GLS. GLS is an excellent noninvasive tool for early detection of subclinical LV and RV systolic dysfunction in patients with CTD.
\end{abstract}

Keywords: Connective tissue diseases; Heart failure; Cardiovascular disease. 


\section{INTRODUCTION}

The involvement of inflammation in the development of heart disease has been recently recognized. Connective tissue diseases can be considered as a 'normal experiment' in the interaction between chronic inflammation and heart disease, with the possibility of detecting the basic processes through which it accelerates the development of atherosclerosis and heart disease. Rheumatoid Arthritis (RA), SLE, Anti-phospholipid syndrome, systemic scleroderma are all chronic inflammatory diseases that affect the joints, skin and eyes lungs and kidneys, but it can also affect the heart and vascular system (Mateen et al., 2016).

However, because much of this process can be asymptomatic, it can be difficult to diagnose. However, early identification of cardiac abnormalities is critical, as it can help guide preventative treatments. Because of its wide availability, portability, cheap cost, and the absence of ionizing radiation, and highly skilled in its use among cardiologists, echocardiography remains more noninvasive imaging modalities that commonly used to screen patients with subclinical cardiac disorders (Mayr et al., 2016 and Mavrogeni et al., 2016).

The development of 2D-STE outlined new implementations of echocardiographic strain imaging that can assess LV and RV systolic functions trough measurement of myocardial deformation expressed in strain and strain rate. Myocardial deformation can be assessed by semi-automated tracking of speckles which provides angleindependent strain measurement (Blessberger and Binder, 2010).
Furthermore, compared to tissue Doppler strain, this approach has the obvious benefit of being easier and faster to assess (Mondillo et al., 2011).

The present work aimed to assess LV and RV systolic functions in patients with connective tissue diseases by $2 \mathrm{D}$ speckle tracking echocardiograpy.

\section{PATIENTS AND METHODS}

This was a case control and 120 patients were included. One hundred cases (patients who were diagnosed as connective tissue disease at least one year ago), twenty cases people for control.

It was held at Al-Hussein University Hospital between September 2020 and April 2021.

Inclusion criteria: Mean age: $18-80$ years old. Group I: patients who were diagnosed as connective tissue disease at least one year ago. Group II: Healthy people for control.

Exclusion criteria: Patients with history of left side heart failure and right sided heart failure, e.g patients with corpulmonale, chronic thromboembolism. etc. Patients with ischemic heart diseases. Patients with history of valvular heart disease. Patients with history of congenital heart disease. Paced rhythm patients or arrhythmias. hemodynamically unstable patients. Poor image quality echo that is seen in morbid obesity patients or patients with chest deformities....etc.

\section{All patients were subjected to:}

Full History and physical examination: All patients gave a review of their medical history, including demographic data (age, gender, body mass index [BMI]) and associated co-morbidities in addition to 
general and cardiac examination. Vital signs, e.g heart rate, blood pressure. Signs of heart failure or hemodynamic instability Local cardiac examination.

Twelve-lead surface ECG to exclude any arrhythmia or the presence of $Q$ waves or ST-T wave changes at rest.

Laboratory investigation: $\mathrm{CBC}$, Random blood sugar, HbA1c. Lipid profile (LDL, HDL, total cholesterol \&TG) to detect dyslipidemia. RF, ANA. ESR, CRP. AST, ALT.

2D Transthoracic Echocardiography was performed to all patients and control group and the followings were measured:

LV systolic function: The LV enddiastolic dimensions (LVEDD), LV end systolic dimensions (LVESD), and LV ejection fraction (EF) estimation by Simpson Method. LV Ejection fraction obtained by MM in PLAX view. MAPSE was measured using $\mathrm{M}$-mode imaging in the apical four chamber view. The $\mathrm{M}$ mode cursor was placed on the septal and lateral mitral annulus parallel to the LV walls, then both values were averaged measurement take place from the end of diastole, until maximal expansion in systole. GLS was measured using 2 dimensional STE; the ECG-gated images were obtained in apical long-axis, four and two chamber views at the frame rate of 50-70 per second and stored digitally. The endocardial border of the myocardium was traced automatically and corrected manually, if needed. Segmental strain was presented as a bull- eye map and GLS was automatically calculated (Klaeboe and Edvardsen, 2019).

\section{RV systolic functions:}

1. Assessment of RV dimensions and function by tricuspid annular plane systolic excursion (TAPSE) was measured using M-mode imaging in the apical four chamber view. The Mmode cursor was placed on the lateral tricuspid annulus parallel to the RV walls, measurement take place from the end of diastole, until maximal expansion in systole (normal value $>1.6 \mathrm{~cm})$.

2. Right ventricular free wall longitudinal strain was measured offline by tracing endocardial walls of RV in RV-focused apical four-chamber view in around 10 points in one frame, and then, it will automatically have tracked all over cardiac cycles. Automatically, software divided RV into three parts basal, mid, and apical and then determined GLS of RV free wall (Spruijt et al., 2017).

\section{Statistical analysis:}

IBM SPSS-22 program (Inc, Chicago, IL, USA) has been used to preform statistical analysis. Data have been examined for normal distribution via the Shapiro Walk testing. Qualitative data have been presented as frequency and relative percentage. Chi square testing $(\chi 2)$ has been utilized to determine change among 2 or more groups of qualitative variables. Quantitative data have been presented as mean \pm SD (Standard deviation). Nondependent sample t-testing has been utilized in comparing among 2 nondependent groups of normal distribution variables (parametric data) \&Mann-Whitney testing. $\mathrm{P}$ value $<0.05$ was judged significant. 


\section{RESULTS}

Most of patients among group A were rheumatoid arthritis (35\%) followed by SLE (24\%) and the least prevalent diagnosis was Systemic scleroderma (19\%) (Table 1).

Table (1): Different diagnosis distribution among group A

\begin{tabular}{|c|c|c|}
\hline Group A & $(\mathbf{N = 1 0 0 )}$ & $\mathbf{N}(\boldsymbol{\%})$ \\
\hline Connective tissue diseases & 35 & $35 \%$ \\
\hline Rystemic lupus erythematosus & 24 & $24 \%$ \\
\hline Antiphospholipid syndrome & 22 & $22 \%$ \\
\hline Systemic scleroderma & 19 & $19 \%$ \\
\hline
\end{tabular}

Comparative study between both Cases \& control groups revealed there is no significant difference between the groups regarding demographic data $(\mathrm{p}>0.05)$ (Table 1).

Table (2): Demographic data of the two studied groups

\begin{tabular}{|c|c|c|c|c|}
\hline \multicolumn{2}{|c|}{ Variables $\quad$ Groups } & $\begin{array}{c}\text { Group A } \\
(\mathrm{n}=100)\end{array}$ & $\begin{array}{c}\text { Group B } \\
(n=20)\end{array}$ & $\mathbf{P}$ \\
\hline \multicolumn{2}{|c|}{$\begin{array}{l}\text { Age }(\text { years }) \\
\text { Mean } \pm \text { SD }\end{array}$} & $55.59 \pm 11.8$ & $56.7 \pm 9.54$ & 0.931 \\
\hline \multirow{2}{*}{ Sex } & Male & $46(46 \%)$ & $5(25 \%)$ & \multirow{2}{*}{0.073} \\
\hline & Female & $54(54 \%)$ & $15(15 \%)$ & \\
\hline \multicolumn{2}{|c|}{$\begin{array}{l}\text { Weight }(\mathrm{kg}) \\
\text { Mean } \pm \text { SD }\end{array}$} & $81.89 \pm 8.77$ & $84.6 \pm 8.48$ & 0.361 \\
\hline \multicolumn{2}{|c|}{$\begin{array}{l}\text { Height }(\mathrm{cm}) \\
\text { Mean } \pm \text { SD }\end{array}$} & $170.92 \pm 8.08$ & $170.55 \pm 7.55$ & 0.751 \\
\hline \multicolumn{2}{|c|}{$\begin{array}{c}\text { BMI }\left(\mathrm{kg} / \mathrm{m}^{2}\right) \\
\text { Mean } \pm \mathrm{SD}\end{array}$} & $28.19 \pm 3.93$ & $29.16 \pm 3.17$ & 0.542 \\
\hline \multicolumn{2}{|c|}{$\begin{array}{c}\text { Disease duration (years) } \\
\text { Mean } \pm \text { SD }\end{array}$} & $2.73 \pm 1.65$ & -- & \\
\hline
\end{tabular}

Comparative study between both cases and control groups revealed that there was a significant difference between the groups regarding heart rate $(\mathrm{P}<0.001)$, however there is no statistical significance regarding SBP and DBP $(\mathrm{P}>0.05)$ (Table 3).

Table (3): Vital signs of the two studied groups

\begin{tabular}{|c|c|c|c|c|}
\hline Groups & $\begin{array}{c}\text { Group A } \\
(\mathrm{n}=100)\end{array}$ & $\begin{array}{c}\text { Group B } \\
(\mathrm{n}=20)\end{array}$ & Mwt & P \\
\hline $\begin{array}{c}\text { Heart rate (beat/min) } \\
\text { Mean } \pm \text { SD }\end{array}$ & $92.27 \pm 12.47$ & $77.8 \pm 5.87$ & 4.912 & $\mathbf{0 . 0 2}$ \\
\hline $\begin{array}{c}\text { SBP (mmHg) } \\
\text { Mean } \pm \text { SD }\end{array}$ & $117.45 \pm 8.39$ & $118.51 \pm 7.96$ & 0.913 & 0.931 \\
\hline $\begin{array}{c}\text { DBP (mmHg) } \\
\text { Mean } \pm \text { SD }\end{array}$ & $71.8 \pm 5.93$ & $72.75 \pm 6.38$ & 0.841 & 0.458 \\
\hline
\end{tabular}




\section{ASSESSMENT OF LV AND RV SYSTOLIC FUNCTIONS IN PATIENTS...}

Comparative study between both cases and control groups that revealed a significant difference between the groups regarding diabetes mellitus only
$(\mathrm{P}=0.017)$. Otherwise, there is no statistical significance regarding smoking, HTN and dyslipidemia ( $>>0.05)$ (Table 4).

Table (4): Risk factors distribution among the two studied groups

\begin{tabular}{|c|c|c|c|c|}
\hline Groups & $\begin{array}{c}\text { Group A } \\
(\mathrm{n}=100)\end{array}$ & $\begin{array}{c}\text { Group B } \\
(\mathrm{n}=20)\end{array}$ & $\mathbf{x}^{\mathbf{2}}$ & $\mathbf{P}$ \\
\hline Smoking & $53(53 \%)$ & $9(45 \%)$ & 0.427 & 0.513 \\
\hline Hypertension & $52(52 \%)$ & $7(35 \%)$ & 2.95 & 0.086 \\
\hline Diabetes mellitus & $49(49 \%)$ & $4(20 \%)$ & $\mathbf{5 . 6 8}$ & $\mathbf{0 . 0 1 7}$ \\
\hline Dyslipidemia & $47(47 \%)$ & $7(35 \%)$ & 0.971 & 0.325 \\
\hline
\end{tabular}

Comparative study between both Cases and control groups revealed that there was a significant difference between the groups regarding hemoglobin, ALT
( $\mathrm{p}=0.005,0.037$, respectively) and PLT $(\mathrm{p}<0.001)$. However, there is no significant difference in the rest parameters $(\mathrm{P}>0.05)$ (Table 5).

Table (5): Laboratory parameters of the two studied groups

\begin{tabular}{|c|c|c|c|}
\hline Groups & $\begin{array}{c}\text { Group A } \\
(\mathrm{n}=100)\end{array}$ & $\begin{array}{c}\text { Group B } \\
(\mathrm{n}=20)\end{array}$ & P \\
\hline $\begin{array}{c}\text { Hb }(\mathrm{g} / \mathrm{dL}) \\
\text { Mean } \pm \text { SD }\end{array}$ & $12.38 \pm 1.17$ & $13.19 \pm 1.18$ & $\mathbf{0 . 0 1}$ \\
\hline $\begin{array}{c}\text { PLT }\left(\mathrm{x} 10^{3} / \mathrm{L}\right) \\
\text { Mean } \pm \text { SD }\end{array}$ & $207.32 \pm 21.09$ & $233.1 \pm 26.13$ & $\mathbf{0 . 0 0 2}$ \\
\hline $\begin{array}{c}\text { RBS (mg/dL) } \\
\text { Mean } \pm \text { SD }\end{array}$ & $159.76 \pm 47.92$ & $140.1 \pm 37.32$ & 0.098 \\
\hline $\begin{array}{c}\text { HbA1c } \%) \\
\text { Mean } \pm \text { SD }\end{array}$ & $6.71 \pm 1.38$ & $6.08 \pm 1.13$ & 0.059 \\
\hline $\begin{array}{c}\text { Total cholesterol (mg/dL) } \\
\text { Mean } \pm \text { SD }\end{array}$ & $238.02 \pm 38.72$ & $229.9 \pm 35.01$ & 0.451 \\
\hline $\begin{array}{c}\text { Triglycerides (mg/dL) } \\
\text { Mean } \pm \text { SD }\end{array}$ & $244.1 \pm 88.21$ & $220.5 \pm 73.61$ & 0.416 \\
\hline $\begin{array}{c}\text { LDL (mg/dL) } \\
\text { Mean } \pm \text { SD }\end{array}$ & $134.54 \pm 30.79$ & $129.9 \pm 31.95$ & 0.631 \\
\hline $\begin{array}{c}\text { HDL (mg/dL) } \\
\text { Mean } \pm \text { SD }\end{array}$ & $76.71 \pm 33.35$ & $66.7 \pm 24.3$ & 0.351 \\
\hline $\begin{array}{c}\text { ALT (U/L) } \\
\text { Mean } \pm \text { SD }\end{array}$ & $41.32 \pm 12.89$ & $34.65 \pm 12.93$ & $\mathbf{0 . 0 2 1}$ \\
\hline $\begin{array}{c}\text { AST (U/L) } \\
\text { Mean } \pm \text { SD }\end{array}$ & $32.38 \pm 9.49$ & $33.3 \pm 9.52$ & 0.736 \\
\hline
\end{tabular}


Comparative study between both Cases and control groups revealed significantly higher inflammatory parameters in group
A compared to controls (group B) with $(\mathrm{P}<0.001)$ (Table 6).

Table (6): Inflammatory parameters of the two studied groups

\begin{tabular}{|c|c|c|c|}
\hline Gariables & $\begin{array}{c}\text { Group A } \\
(\mathrm{n}=100)\end{array}$ & $\begin{array}{c}\text { Group B } \\
(\mathrm{n}=20)\end{array}$ & $\mathbf{P}$ \\
\hline $\begin{array}{c}\text { ESR }(\mathrm{mm} / \mathrm{hr}) \\
\text { Mean } \pm \text { SD }\end{array}$ & $45.45 \pm 13.74$ & $15.6 \pm 2.21$ & $\mathbf{0 . 0 2}$ \\
\hline $\begin{array}{c}\text { CRP }(\mathrm{mg} / \mathrm{L}) \\
\text { Mean } \pm \text { SD }\end{array}$ & $39.01 \pm 7.04$ & $8.7 \pm 1.13$ & $\mathbf{0 . 0 0 1}$ \\
\hline $\begin{array}{c}\text { RF }(\mathrm{IU} / \mathrm{ml}) \\
\text { Mean } \pm \text { SD }\end{array}$ & $25.61 \pm 4.95$ & $14.35 \pm 3.34$ & $\mathbf{0 . 0 0 2}$ \\
\hline $\begin{array}{c}\text { ANA } \\
\text { Mean } \pm \text { SD }\end{array}$ & $73.1 \pm 15.46$ & $30.5 \pm 5.48$ & $\mathbf{0 . 0 0 1}$ \\
\hline
\end{tabular}

Comparative study between both Cases and control groups that revealed that there was a highly significant difference between the groups regarding GLS and MAPSE $(\mathrm{P}<0.001)$ (Table 7).

Table (7): Echocardiographic LV parameters of the studied group

\begin{tabular}{|c|c|c|c|}
\hline Groups & $\begin{array}{c}\text { Group A } \\
(\mathrm{n}=100)\end{array}$ & $\begin{array}{c}\text { Group B } \\
(\mathrm{n}=20)\end{array}$ & P \\
\hline $\begin{array}{c}\text { LVEDD (mm) } \\
\text { Mean } \pm \text { SD }\end{array}$ & $46.91 \pm 5.03$ & $45.89 \pm 5.14$ & 0.417 \\
\hline $\begin{array}{c}\text { LVESD (mm) } \\
\text { Mean } \pm \text { SD }\end{array}$ & $29.49 \pm 4.62$ & $27.87 \pm 3.35$ & 0.319 \\
\hline $\begin{array}{c}\text { LVEF (\%) } \\
\text { Mean } \pm \text { SD }\end{array}$ & $62.72 \pm 6.65$ & $63.25 \pm 6.38$ & 0.954 \\
\hline $\begin{array}{c}\text { LV-GLS (\%) } \\
\text { Mean } \pm \text { SD }\end{array}$ & $-11.67 \pm 1.33$ & $-18.21 \pm 0.586$ & $\mathbf{0 . 0 1}$ \\
\hline $\begin{array}{c}\text { MAPSE (mm) } \\
\text { Mean } \pm \text { SD }\end{array}$ & $12.08 \pm 2.3$ & $10.08 \pm 1.44$ & $\mathbf{0 . 0 3}$ \\
\hline
\end{tabular}


Comparative study between both Cases annd control groups revealed significant difference between the groups regarding
RVEDD， RVESD， RVEF， GLS and TAPSE with $(\mathrm{P}<0.001)$ (Table 8).

Table (8): Echocardiographic RV parameters of the studied groups

\begin{tabular}{|c|c|c|c|}
\hline Variables $\quad$ Groups & $\begin{array}{c}\text { Group A } \\
(n=100)\end{array}$ & $\begin{array}{c}\text { Group B } \\
(\mathrm{n}=20)\end{array}$ & $\mathbf{P}$ \\
\hline $\begin{array}{c}\text { RVEDD }(\mathrm{mm}) \\
\text { Mean } \pm \text { SD }\end{array}$ & $23.51 \pm 3.72$ & $46.99 \pm 5.32$ & 0.001 \\
\hline $\begin{array}{l}\text { RVESD }(\mathrm{mm}) \\
\text { Mean } \pm \text { SD }\end{array}$ & $8.01 \pm 1.33$ & $24.96 \pm 10.95$ & 0.003 \\
\hline $\begin{array}{l}\text { RVEF (\%) } \\
\text { Mean } \pm \text { SD }\end{array}$ & $46.04 \pm 6.02$ & $54.1 \pm 3.32$ & 0.001 \\
\hline $\begin{array}{c}\text { RV-GLS (\%) } \\
\text { Mean } \pm \text { SD }\end{array}$ & $-15.74 \pm 6.45$ & $-25.38 \pm 6.58$ & 0.002 \\
\hline $\begin{array}{c}\text { TAPSE }(\mathrm{mm}) \\
\text { Mean } \pm \text { SD }\end{array}$ & $25.49 \pm 4.73$ & $21.25 \pm 2.79$ & 0.001 \\
\hline
\end{tabular}

There was a positive correlation between LV-GLS with BMI, total cholesterol and LDL, while there is a negative correlation between LV-GLS with DBP (Table 9).

Table (9): Correlation between GLS and LV parameters of the studied patients

\begin{tabular}{|c|c|c|}
\hline Lroup A & $\mathrm{r}$ & $\mathrm{P}$ \\
\hline Age & 0.459 & 0.075 \\
\hline BMI & $\mathbf{0 . 2 1 8}$ & $\mathbf{0 . 0 2 9} *$ \\
\hline SBP & 0.429 & 0.080 \\
\hline DBP & $\mathbf{- 0 . 2 5 4}$ & $\mathbf{0 . 0 1 1} *$ \\
\hline Hb & 0.098 & 0.166 \\
\hline Platelet & 0.342 & 0.096 \\
\hline RBS & 0.108 & -0.162 \\
\hline HbA1c & -0.007 & 0.945 \\
\hline Total Cholesterol & $\mathbf{0 . 6 2 0}$ & $\mathbf{0 . 0 4 9} *$ \\
\hline Triglycerides & 0.599 & 0.053 \\
\hline LDL & $\mathbf{0 . 7 7 9}$ & $\mathbf{0 . 0 2 8} *$ \\
\hline HDL & -0.289 & 0.107 \\
\hline RF & -0.183 & 0.134 \\
\hline ANA & 0.377 & 0.089 \\
\hline ESR & -0.270 & 0.111 \\
\hline CRP & 0.039 & 0.699 \\
\hline LVEDD & 0.116 & 0.871 \\
\hline LVESD & -0.607 & 0.058 \\
\hline LVEF & 0.435 & 0.079 \\
\hline MAPSE & -0.345 & 0.095 \\
\hline
\end{tabular}


There was a positive correlation between RV-GLS with TAPSE, while there is a negative correlation between

RV-GLS with RVEDD and RVESD (Table 10).

Table (10): Correlation between GLS and RV parameters of the studied patients

\begin{tabular}{|c|c|c|}
\hline Group B & & \\
\hline AgV-GLS & $\mathrm{r}$ & $\mathrm{P}$ \\
\hline BMI & -0.194 & 0.053 \\
\hline SBP & 0.125 & 0.217 \\
\hline DBP & 0.184 & 0.067 \\
\hline Hb & -0.184 & 0.141 \\
\hline Platelet & -0.020 & 0.844 \\
\hline RBS & 0.040 & 0.689 \\
\hline HbA1c & 0.091 & 0.369 \\
\hline Total Cholesterol & 0.121 & 0.229 \\
\hline Triglycerides & 0.130 & 0.196 \\
\hline LDL & 0.165 & 0.100 \\
\hline HDL & 0.123 & 0.224 \\
\hline RF & 0.042 & 0.679 \\
\hline ANA & -0.146 & 0.146 \\
\hline ESR & 0.534 & 0.063 \\
\hline CRP & -0.480 & 0.071 \\
\hline RVEDD & 0.478 & 0.082 \\
\hline RVESD & $\mathbf{- 0 . 5 1 9}$ & $\mathbf{0 . 0 1 1}^{*}$ \\
\hline RVEF & $\mathbf{- 0 . 4 0 7}$ & $\mathbf{0 . 0 4 8} *$ \\
\hline TAPSE & 0.052 & 0.195 \\
\hline & $\mathbf{0 . 4 3 6}$ & $\mathbf{0 . 0 3 9}^{*}$ \\
\hline
\end{tabular}

There was a positive correlation between disease duration with LV-GLS and RV-GLS respectively) (Table 2 ).

Table (11): Correlation between Disease duration and GLS of left and right ventricles of the studied patients

\begin{tabular}{|c|c|c|}
\hline Group A Disease duration & r & P \\
\hline LV-GLS & $\mathbf{0 . 4 4 7}$ & $\mathbf{0 . 0 1 7} *$ \\
\hline RV-GLS & $\mathbf{0 . 3 9 7}$ & $\mathbf{0 . 0 2 7} *$ \\
\hline
\end{tabular}

\section{DISCUSSION}

This was a case-control study conducted on 120 subjects (100 connective tissue disease cases and 20 healthy controls); to assess LV systolic function and RV systolic function in connective tissue disease patients by $2 \mathrm{D}$ speckle tracking Echocardiography. The
120 patients were classified according to presence of connective tissue diseases into 2 independent groups: Group A: connective tissue diseases patients (100 patients), and Group B: (20 healthy controls).

In the current study, the most common diagnosis among group A was rheumatoid 
arthritis (35\%) followed by SLE (24\%), and the least prevalent diagnosis was Systemic scleroderma (19\%). Majority of cases in both groups were females, and a comparative study between both cases and control groups revealed no significant difference between the groups regarding demographic data. Furthermore, the current study revealed a significant difference between the groups regarding diabetes mellitus only. Otherwise, there was no statistical significance regarding smoking, HTN and dyslipidemia ( $\mathrm{p}>0.05)$.

Another study done by Farag et al. (2020) reported that six patients (12\%) were diabetic in the control group, while only three patients (6\%) in the SLE group with no significant difference. The number of hypertensive patients was the same in the control group and SLE group 18 patients $(36 \%)$.

In the present study, there was a significant difference between the groups regarding hemoglobin, ALT and PLT. However, there was no significant difference in the rest parameters. Also inflammatory parameters as ESR, CRP, $\mathrm{RF}$ and ANA were significantly higher in group A compared to controls (group B).

Naseem et al. (2019) reported that the inflammatory markers CRP and ESR were significantly higher in the active RA group compared to the RA in remission and control groups.

Early systolic dysfunction can be detected by assessment of strain and strain rate of global myocardium or predefined myocardial segments in standardized planes (Benacka et al. 2016).

In the present study, as regard Echocardiographic LV parameters of the studied group's shows significant difference between the groups regarding GLS (more negative GLS in CTDs) patients and MAPSE. RV echocardiography showed a highly significant difference between the groups regarding RVEDD, RVESD, GLS (more negative GLS in CTDs patients) and TAPSE.

Naseem et al. (2019) reported that the groups did not differ with respect to LV septum thickness at end diastole, LV posterior wall thickness at end diastole, LV end diastolic volume, LV end-systolic volume, EF. The LV GLS value for active RA patients was significantly worse (less negative) compared to RA patients in remission and control group. Of note, the LV GLS value was comparable between patients with RA in remission and control group. While as regard RV echocardiography, here were no significant differences between the three groups regarding, TAPSE, RVFAC, MPITDI. The RV GLS value for active RA patients was significantly worse (less negative) compared to RA patients in remission and control group. The RV GLS value did not differ between patients with $\mathrm{RA}$ in remission and control group.

Farag et al. (2020) reported that there were statistically significant differences between the control group and the SLE group regarding apical four-chamber longitudinal strain (AP4C LS), apical twochamber longitudinal strain (AP2C LS), apical three-chamber longitudinal strain (AP3C LS) and GLS.

Nikdoust et al. (2018) showed a significant decrease in the LV GLS in the case group in comparison with the healthy controls. Similarly, in the comparison 
between the patients with SLE and the healthy controls in terms of the echocardiographic parameters, the LV GLS in the apical 3-chamber view was significantly lower in the case group than in the control group. In contrast, the LV GLS in the apical 4-chamber view revealed no significant difference between the case and control groups. Whereas the difference between the case and control groups as regards the LV GLS constituted a statistically significant difference, the 2 study groups were not statistically significantly different concerning the LVEF measured with the Simpson method.

Gokdeniz et al. (2015) reported that STE might be a sensitive and valuable method to detect early LV systolic impairment in patients with systemic sclroederma and preserved LVEF, The LVEF remained unchanged, but the global longitudinal peak systolic strain of the left ventricle was significantly lower. The regional analysis showed a heterogeneous distribution of segmental systolic dysfunction that did not match any particular coronary artery distribution.

Ntusi et al. (2014) showed that conventional echocardiographic characteristics of APS patients revealed there are no wall motion abnormalities, neither moderate nor severe valvular, acute or chronic myocardial or pericardial disease. Left ventricular ejection fraction was similar to the control group. Speckletracking echocardiography characteristics of the patient population: average GLS values were lower in APS patients than in controls.

GLS impairment has an early diagnostic and prognostic value. This finding was in line with the results of a study by Huang et al. (2014) who reported a reduction in the LV GLS in 2D echocardiography in their patients with lupus by comparison with their healthy subjects. A similar study of Acar et al. (2016) indicated that the strain indices decreased in the treatment-resistant lupus group compared with the non-resistant lupus group. These findings underscore the importance of strain in predicting the disease prognosis and response to treatment in patients with lupus.

On light of the above findings, it can be stated that impairment in GLS can be used as an index for evaluating early systolic left ventricular and right ventricular dysfunctions relative to the conventional EF measurement in patients with CTDs.

As regard the correlation between GLS and LV parameters of the studied patients, there was a positive correlation between LV-GLS with BMI, total cholesterol and LDL, while there is a negative correlation between LV-GLS with DBP. Moreover, we found that there is a positive correlation between RV-GLS with TAPSE, while there is a negative correlation between RV-GLS with RVEDD and RVESD.

Farag et al. (2020) reported that there was a statistically significant positive correlation between the disease duration and GLS (\%), while there was no significant difference between the disease duration and the remaining parameters. It is also in agreement with the results obtained by Bakhoum et al. (2015) who found that STE showed a significantly lower GLS in the SLE group. Similar results were obtained by Buss et al. (2010) 
and Guşetu et al. (2016) who reported that longitudinal strain was significantly reduced in the SLE group.

In a meta-analysis done by Di Minno et al. (2020) to evaluate the role of speckle tracking in patients with SLE, they found that GLS was significantly lower in SLE patients than non-SLE controls. Similarly, Du Toit et al. (2017) reported that GLS decreased significantly in lupus myocarditis patients in comparison to the healthy control group.

The previous finding was supported by Midtbø et al. (2017) who found that stress-corrected mid wall shortening (scMWS) and GLS, both reflect myocardial function, reduced in patients with active RA compared with patients with RA in remission.

In another study of Fine et al. (2014) found more negative GLS in RA patients (more worse function).

In addition to above findings, in the current study, there was a positive correlation between disease duration with LV-GLS and RV-GLS.

\section{CONCLUSION}

The GLS parameters in 2D speckle tracking echocardiography are a noninvasive cost-effective tool with a desirable diagnostic value in patients with CTD. GLS impairment was common in 2D speckle tracking echocardiography findings in our patients with CTD. Connective tissue disease patients had GLS \% lower than the control group denoting early systolic dysfunction. Longer duration and high disease activity index significantly affect GLS. GLS is an excellent noninvasive tool for early detection of subclinical left ventricular systolic dysfunction and right ventricular systolic dysfunction in patients with connective tissue diseases.

\section{REFERENCES}

1. Acar RD, Bulut M, Acar Ş, Efe SÇ, Fidan $S$, Yesin $M$ and Gürbüz AS (2016): Systemic lupus erythematosus disease activity index is related with increased aortic stiffness and decreased left ventricular longitudinal strain as shown by two-dimensional speckle tracking echocardiography. Turkish Journal of Thoracic and Cardiovascular Surgery, 24(1): 1-10.

2. Bakhoum SW, El Basel M, Alnaggar AR, Hamdy MS and Hussein H (2015): Assessment of left ventricular function in systemic lupus erythematosus patients by speckle tracking echocardiography: Relation to circulating endothelial progenitor cells. The Egyptian Rheumatologist, 37(4): 33-41.

3. Benacka O, Benacka J, Blazicek $P$, Belansky M, Payer J, Killinger $Z$ and Lietava J (2016): Speckle-tracking Echocardiography is More Sensitive in Detecting Subclinical Myocardial Dysfunction in Patients with Rheumatoid Arthritis. J Arthritis, 5(6):1-8.

4. Blessberger $H$ and Binder $T$ (2010): Two dimensional speckle tracking echocardiography: basic principles. Heart, 96(9): 716-722.

5. Buss SJ, Wolf D, Korosoglou G, Max R, Weiss CS, Fischer $\mathrm{C}$ and Hansen A (2010): Myocardial left ventricular dysfunction in patients with systemic lupus erythematosus: new insights from tissue Doppler and strain imaging. The Journal of rheumatology, 37(1): 79-86.

6. Di Minno MND, Forte F, Tufano A, Buonauro A, Rossi FW, De Paulis A and Galderisi $M$ (2020): Speckle tracking echocardiography in patients 
with systemic lupus erythematosus: A meta-analysis. European journal of internal medicine, 73: 16-22.

7. Du Toit R, Herbst PG, Van Rensburg $A$, Snyman HW, Reuter $H$ and Doubell AF (2017): Speckle tracking echocardiography in acute lupus myocarditis: comparison to conventional echocardiography. Echo research and practice, 4(2): 9-19.

8. Farag SI, Bastawisy RB, Hamouda MA, Hassib WA and Wahdan HA (2020): Value of Speckle Tracking Echocardiography for Early Detection of Left Ventricular Dysfunction in Patients with Systemic Lupus Erythematosus. Journal of Cardiovascular Echography, 30(3): 140-145.

9. Fine NM, Crowson CS, Lin G, Oh JK, Villarraga HR and Gabriel SE (2014): Evaluation of myocardial function in patients with rheumatoid arthritis using strain imaging by speckle-tracking echocardiography. Annals of the rheumatic diseases, 73(10): 1833-1839.

10. Gokdeniz T, Erkol A, Kalaycioglu E, Cagri Aykan A, Gul I and Boyaci F (2015): Relation of epicardial fat thickness to subclinical right ventricular dysfunction assessed by strain and strain rate imaging in subjects with metabolic syndrome: a two-dimensional speckle tracking echocardiography study. Echocardiography. 32(2): 248-56.

11. Guşetu G, Pop D, Pamfil C, Bălaj R, Mureşan L, Cismaru $G$ and Rednic $S$ (2016): Subclinical myocardial impairment in SLE: insights from novel ultrasound techniques and clinical determinants. Medical ultrasonography, 18(1): 47-56.

12. Huang BT, Yao HM and Huang $H$ (2014): Left ventricular remodeling and dysfunction in systemic lupus erythematosus: a three-dimensional speckle tracking study. Echocardiography, 31(9): 1085-1094.

13. Klaeboe LG and Edvardsen T (2019): Echocardiographic assessment of left ventricular systolic function. Journal of Echocardiography. 17(1):10-6.

14. Mateen S, Zafar A, Moin S, Khan AQ and Zubair $S$ (2016): Understanding the role of cytokines in the pathogenesis of rheumatoid arthritis. Clinica chimica acta, 455: 161-171.

15. Mavrogeni SI, Kitas GD and Dimitroulas $T$ (2016): Cardiovascular magnetic resonance in rheumatology: current status and recommendations for use. Int J Cardiol 217:135-148.

16. Mayr A, Kitterer D, Latus J, Steubing H, Henes J, Vecchio F, Kaesemann P, Patrascu A, Greiser A, Groeninger S, Braun N, Alscher MD, Sechtem U, Mahrholdt $H$ and Greulich S (2016): Evaluation of myocardial involvement in patients with connective tissue disorders: a multi-parametric cardiovascular magnetic resonance study. Journal of cardiovascular magnetic resonance : official journal of the Society for Cardiovascular Magnetic Resonance, 18(1): 67.

17. Midtbø H, Semb AG, Matre K, Kvien TK and Gerdts E (2017): Disease activity is associated with reduced left ventricular systolic myocardial function in patients with rheumatoid arthritis. Annals of the Rheumatic Diseases, 76(2): 371-376.

18. Mondillo S, Galderisi M, Mele D, Cameli M, Lomoriello VS, Zacà V and Badano L (2011): Speckle-tracking echocardiography: a new technique for assessing myocardial function. Journal of Ultrasound in Medicine, 30(1): 71-83. 
19. Naseem M, Samir S, Ibrahim IK, Khedr L and Shahba AAE (2019): 2-D speckle-tracking assessment of left and right ventricular function in rheumatoid arthritis patients with and without disease activity. Journal of the Saudi Heart Association, 31(1): 41-49.

20. Nikdoust, F., Bolouri, E., Tabatabaei, S. A., Goudarzvand, M. and Faezi, S. T. (2018): Early diagnosis of cardiac involvement in systemic lupus erythematosus via global longitudinal strain (GLS) by speckle tracking echocardiography. Journal of cardiovascular and thoracic research, 10(4): 231-235.

21. Ntusi NA, Piechnik SK, Francis JM, Ferreira VM, Rai AB and Matthews PM (2014): Subclinical myocardial inflammation and diffuse fibrosis are common in systemic sclerosis--a clinical study using myocardial T1-mapping and extracellular volume quantification. $\mathbf{J}$ Cardiovasc Magn Reson, 88(3): 16:21.

22. Spruijt OA, Di Pasqua MC, Bogaard $\mathrm{HJ}$, van der Bruggen CE, Oosterveer F, Marcus JT, Vonk-Noordegraaf A, Handoko ML (2017): Serial assessment of right ventricular systolic function in patients with precapillary pulmonary hypertension using simple echocardiographic parameters: a comparison with cardiac magnetic resonance imaging. Journal of Cardiology, 69(1):182-8. 


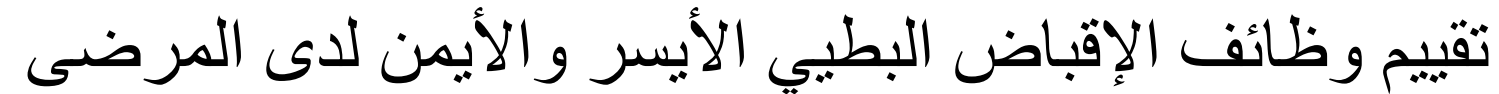

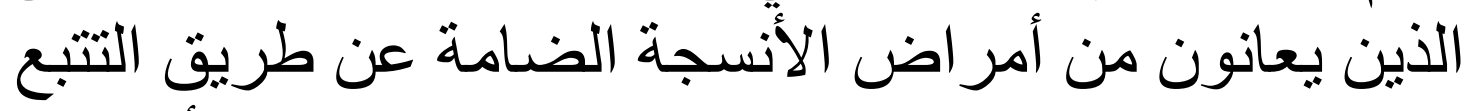
النقطي لعضلة القلب بالموجات الصونية ثنائية الأبعاد عبد الرحمن علي حسيني، كمال أحمد ميرغني، عبد الحميد إسماعيل عبد الحميد، محمد مجدي غيط

قسم أمراض القلب، قسم الروماتيزم والتأهيل جامعة الأزهر (بنين- القاهرة)

E-mail: 3bdulra7manz@gmail.com

خلفية البحث: يزداد خطر الإصابة بأمر اض القلب في المرضى الذين يعانون من إضطرابات النسيج

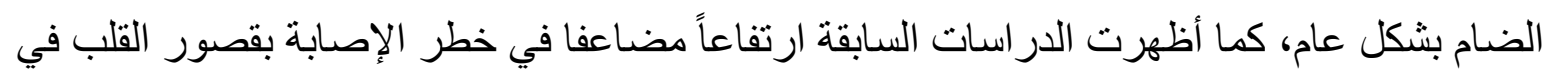
مرضى اضطر ابات النسيج الضام. يحدث قصور القلب غير الإقفاري في مرضى إلتهاب الدفاصل

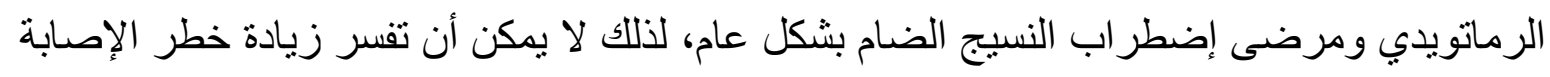

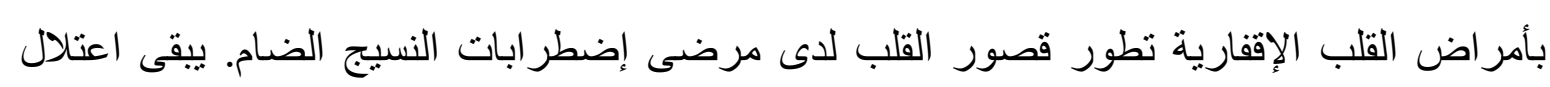

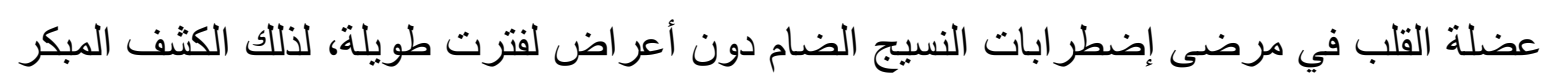
عن قصور القلب في المراحل المتقدمة لمرضى اضطر اب النسيج الضام قد يساعد في التدخل بالعلاج الوقائي لمنع تطور قصور القلب.

الهلف من البحث: تقيبم وظائف الإقباض البطيي الأيسر والأيمن لدى المرضى الذين يعانون من

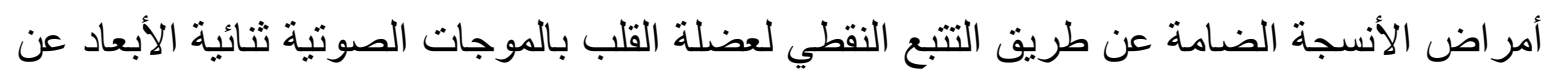

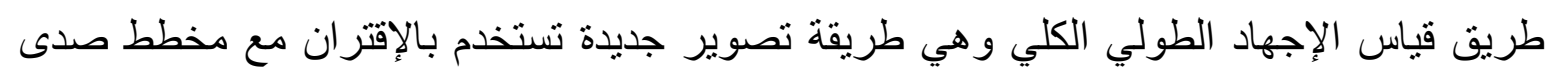

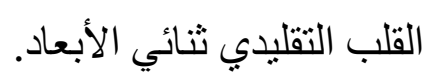

المرضى وطرق البحث: كانت هذه در اسة حالة وشو اهد أجريت على 120 شخصا لتقييم وظيفة البطين

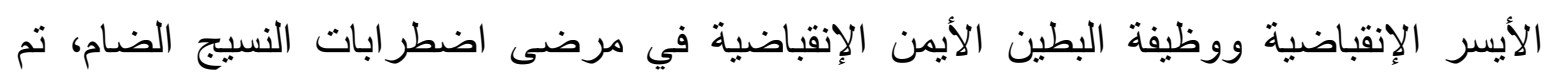
تصنيف 120 شخصا وفقا لوجود أمراض اضطر ابات النسيج الضام في مجموعتين مستقلتين:

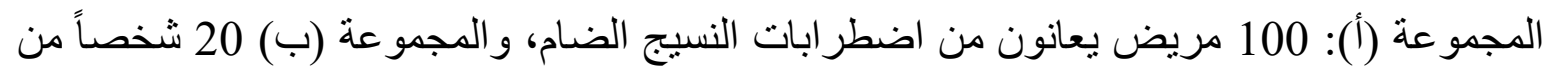

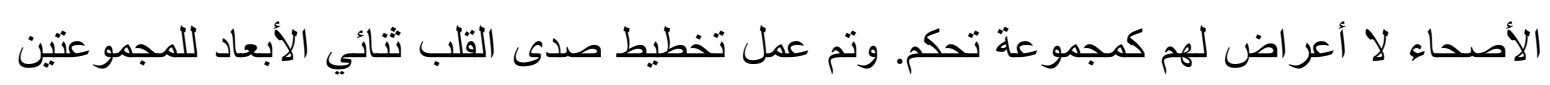
وقياس الإجهاد الطولي الكلي بالتتبع النقطي لعضلة القلب بمستثفى الحسين الجامعي بين سبتمبر 2020 و أبريل 2021. 


\section{ASSESSMENT OF LV AND RV SYSTOLIC FUNCTIONS IN PATIENTS... 747}

تتائج البحث: كان التشخيص الأكثر انتشار اً بين المجموعة (أ) هو إلتهاب المفاصل الروماتويدي يليه مرض الذئبة الحمر اء وكان أقل التشخيص انتشاراً هو تصلب الجلد الجهازي، وكانت غالبية الحالات من الإناث. فيما يتعلق بتخطيط صدى القلب للبطين الأيسر للمجموعات المدروسة، وجدنا أن هناك فرقاً ذا دلالة إحصائية بين المجموعات فيما يتعلق بالإجهاد الطولي الكلي بالتتبع النقطي للبطين الأيسر، وأظهرت الاراسات إنخفاضاً كبيرا في الإجهاد الطولي الكلي للبطين الأيسر بين مجموعة لإِي مرضى إضطر اب النسيج الضام، كما أظهرت قياسات الإرتباط الخطي وجود إرتباطاً إيجابياً بين الإجهاد الطولي الكلي و الإنحراف الإنقباضي المسطح الحلقي الميتر الي. فيما يتعلق بتخطبط صدى القلب للبطين الأيمن للمجموعات المدروسة، وجدنا أن هناك فرقاً ذا دلالة إحصائية بين المجموعات فيما يتعلق بالإجهاد الطولي الكلي بالتبع النقطي للبطين الأيمن، و أظهرت الدر اسات إنخفاضاً كبير الي في الإجهاد الطولي الكلي للبطين الأيمن بين مجمو عة مرضى إضطر اب النسيج الضام، وتبين أيضاً وجود علافة إيجابية بين مدة المرض مع الإجهاد الطولي الكلي بالتتبع النقطي للبطين الأيسر والإجهاد الطولي بالتتبع النقطي للبطين الأيمن.

الإستتتاج: يعتبر قياس الإجهاد الطولي الكلي بالتتبع النقطي للبطين الأيسر والبطين الأيمن طريقة مفيدة في توقع إعتلال الوظيفة الإنقباضية للبطين الأيسر والبطين الأبين للقلب بين مرضى النسيج الضنام.

الكلمات الدالة: التتبع النقطي لعضلة القب بالموجات الصوتية ثنائية الأبعاد، اضطر اب النسيج الضام، الإجهاد الطولي الكلي للبطين الأيسر والأيمن، قصور القلب. 